\title{
KAJIAN MARJIN PEMASARAN KOPRA DI KECAMATAN OBA DI KOTA TIDORE KEPULAUAN
}

\author{
Arman Drakel \\ Dosen Fakultas Pertanian UMMU-Ternate, $\boldsymbol{e}$-mail : -
}

\begin{abstract}
ABSTRAK
Tujuan penelitian adalah untuk mengetahui besarnya margin yang diperoleh setiap lembaga pemasaran dan efesiensi pemasaran pada setiap saluran pemasaran serta faktor-faktor yang mempengaruhi besar kecilnya marjin pemasaran di dalam proses pemasaran kelapa biji, kopra dan minyak kelapa di Kecamatan Oba. Penelitian ini untuk melihat populasi petani kelapa dan pedagang yang terlibat dalam rantai pemasaran kopra di Kecamatan Oba Kota Tidore Kepulauan. Penarikan sampel dilakukan secara Purposive sampling yaitu sebagai subyek dari populasi guna dijadikan responden sebanyak 20 orang petani kelapa di empat (4) desa, Kecamatan Oba yaitu Desa Gita, Desa Toseho, Desa Payahe dan Desa Kusu Sinopa yaitu 4 orang pengumpul kelapa dan 6 orang pedagang kopra. Semua sampel di atas terlibat dalam rantai pemasaran dan dianggap mewakili populasi.

Hasil penelitian menunjukkan bahwa (1) dalam proses pemasaran kopra di Kecamatan Oba, marjin terbesar diperoleh yaitu pedagang pengecer dan pedagang pengumpul ke Kabupaten. (2) Saluran pemasaran yang efisien dalam proses pemasaran kopra di Kecamatan Oba adalah pemasaran II, yang masing-masing memperoleh presentase yang lebih rendah dibanding presentase pada saluran pemasaran I, (3) Faktor-faktor yang mempengaruhi besar kecilnya marjin pemasaran kopra adalah biaya pemasaran dan keuntungan pemasaran, sebab nilai t-hitung kedua variabel tersebut lebih besar dibanding t-tabel.
\end{abstract}

\section{Kata Kunci : Ekonomi Pertanian, Marjin Pemasaran, Kopra}

\section{PENDAHULUAN}

\subsection{Latar Belakang}

Pengembangan sektor agribisnis dalam pengelolaan komoditi kelapa berhubungan dengan aspek budidaya, khususnya penyesuaian karasteristik wilayah. Tanaman kelapa dapat ditanam di dataran rendah, pasang surut, ladangladang rakyat, persawahan, sampai ke daerah-daerah pegunungan hingga mencapai ketinggian 900 diatas permukaan laut.

Pengembangan dalam sektor agribisnis tanaman kelapa sangat penting sebagai pohon kehidupan dengan berbagai aspek fungsi. Karena bagian tanaman dapat dimanfaatkan untuk kebutuhan manusia. Jika ditelaah penggunaan pengelolaan kelapa dalam proses produksi sangat berhubungan dengan proses pengelolaan kopra untuk kepentingan industri minyak kelapa, industri pembuatan sabun dan bahan sumber nabati lainnya.

Melihat tingkat konsumsi kelapa pada skala nasional diperkirakan meningkat sekitar 5,5\% tahun. Dengan laju peningkatan produksi hanya sekitar $4,37 \%$ tahun. Hal ini menunjukan bahwa produksi kopra dari tahun ke tahun belum mencukupi dengan kenaikan konsumsinya. Peningkatan produksi kopra dapat dilihat dari aspek pemasaran. Sebab aspek 
pemasaran kopra merupakan potensi yang cukup signifikan dalam peningkatan produksi kelapa petani. Untuk memenuhi laju pertumbuhan konsumsi tersebut perlu upaya peningkatan produksi kelapa. Hal ini dapat dicapai apabila budi daya kelapa tersebut mampu dikelola dengan baik, sehingga dapat mencapai produksi 1,5 ton kopra/ha/tahun (Suhardiyono, 1993).

Untuk melaksanakan proses pemasaran kopra dari petani atau produsen ke konsumen akhir kadang-kadang memerlukan waktu yang cukup lama. Hal ini menimbulkan resiko dan biaya pemasaran yang dikeluarkan tidak efisien. Untuk itu perlu pengkajian kembali secara komprehensif sistem pemasaran produk kopra yang paling efisien dilakukan, dapat memberikan konstribusi pendapatan yang proporsional bagi petani.

Proses pemasaran kopra di Kecamatan Oba Kota Tidore Kepulauan dari petani ke konsumen akhir banyak lembaga pemasaran yang terlibat di dalamnya. Akan berdampak terhadap petani dalam berusaha, dibandingkan lembaga pemasaran dengan kekayaan yang dimiliki. Oleh karena itu diperlukan Kajian margin pemasaran kopra di Kecamatan Oba Kota Tidore Kepulauan”.

\subsection{Perumusan Masalah}

Darii latar belakang masalah yang dikemukakan, dapat dirumuskan masalah sebagai berikut :

1. Seberapa besar marjin pemasaran kopra yang diperoleh setiap lembaga pemasaran di Kecamatan Oba Kota Tidore Kepulauan?

2. Bagaimana saluran pemasaran kopra di Kecamatan Oba Kota Tidore Kepulauan?

\subsection{Tujuan dan Kegunaan Penelitian}

a. Tujuan Penelitian ini adalah :

1. Mengetahui besarnya marjin pemasaran yang diperoleh setiap lembaga pemasaran di dalam proses pemasaran kopra di Kecamatan Oba Kota Tidore Kepulauan.
2. Untuk mengetahui saluran pemasaran kopra yang di ada di Kecamatan Oba Kota Tidore Kepulauan.

b. Kegunaan penelitian adalah sebagai bahan kajian ilmiah dalam upaya melakukan kebijakan sektor agribisnis pemasaran kopra yang menguntungkan petani di Kecamatan Oba, Kota Tidore Kepulauan.

\section{METODOLOGI PENELTIAN}

\subsection{Tempat dan Waktu Penelitian}

Penelitian ini akan dilaksanakan di Kecamatan Oba Kota Tidore Kepulauan pada bulan Februari 2010. Lokasi penelitian ini dipertimbangan Kecamatan Oba merupakan salah satu proses produksi kopra yang berada di Kota Tidore Kepulauan.

\subsection{Populasi dan Sampel}

Populasi dalam penelitian ini adalah semua produsen kopra dan pedagang yang terlibat dalam rantai pemasaran kopra dan di Kecamatan Oba Kota Tidore Kepulauan.

Pengambilan sampel dilakukan secara purposive sampling, dengan responden sebanyak 20 orang produsen kopra di empat desa di Kecamatan Oba yaitu Desa Gita, Desa Toseho, Desa Payahe, dan Desa Kusu Sinopa serta 6 orang pedagang, 4 orang pedagang kopra. Semua sampel di atas terlibat dalam rantai pemasaran dan dianggap respresentatif mewakili populasi.

\subsection{Jenis dan Sumber Data}

Data yang dibutuhkan dalam penelitian ini adalah sebagai berikut:

1. Data Primer

Yaitu data yang diperlukan langsung di lapangan melalui observasi dan wawancara dengan petani kelapa dan lembaga pemasaran kopra sebagai responden.

2. Data Sekunder

Data yang diperoleh dari berbagai instansi terkait, antara lain Dinas 
Pertanian, Biro Pusat Statistik, dan Dinas Perindustrian dan Perdagangan.

\subsection{Teknik Pengumpulan Data}

Teknik pengumpulan data yang digunakan dalam penelitian ini adalah :

1. Wawancara

Yaitu mengumpulkan data secara langsung dari petani kelapa dan lembaga pemasaran kopra.

2. Observasi

Yaitu langsung mengamati aktivitas petani kelapa dan lembaga pemasaran kopra.

3. Dokumentasi

Yaitu pengumpulan data dan jurnaljurnal, buku-buku dan hasil penelitian yang berkaitan dengan penelitian ini.

\subsection{Analisis Data}

Data dianalisis secara kuantitatif, untuk memperoleh gambaran tentang margin pemasaran kopra pada lembaga pemasaran yang ada di Kecamatan Oba Kota Tidore Kepulauan. Untuk menjawab hipotesis pertama formula yang dipakai (Soekartawi, 1993):

$$
\begin{array}{r}
\mathrm{M}=\mathrm{B}+\pi, \ldots \ldots \ldots \ldots \ldots \ldots \ldots \ldots \\
\mathrm{M}=\text { Penjualan - Pembelian }
\end{array}
$$

Dimana:

$\mathrm{M}=$ Margin Pemasaran

$\mathrm{B}=$ Biaya Pemasaran

$\pi=$ Keuntungan

\section{KONDISI UMUM LOKASI PENELITIAN}

\subsection{Tipologi Kecamatan Oba}

Kecamatan Oba adalah salah satu dari 5 kecamatan di Kota Tidore Kepulauan yang teiietak di bagian tengah Pulau Halrnahera.

Kecamatan Oba terletak ditengah Pulau Halrnahera dengan batas-batas :

a. Sebelah Utara :Berbatasan dengan Kecamatan Oba Utara

b. Sebelah Selatan :Berbatasan dengan Kecamatan Gane Barat

c. Sebelah Timur:Berbatasan dengan Kecamatan Weda d. Sebelah Barat:Berbatasan dengan Kecamatan Kayoa.

\section{Luas Wilayah}

Data Monografi Kota Tidore Kepulauan, (2009), bahwa Wilayah Kecamatan Oba membawahi 7 desa dengan 22 dusun/anak desa, dengan luas wilayah $6.31 \mathrm{Km}^{2}$.

\section{Potensi Ekonomi}

Permintaan pasar terhadap kopra terus meningkat seiring dengan kebutuhan konsumen. Hal ini mengisyaratkan produk kopra amat cerah, baik di pasar dalam negeri maupun luar negeri sebagai komoditas eksport.

\section{Lembaga Pemasaran}

Produk kopra rnerniliki lembaga pemasaran yang tersedia di masing-masing desa, Kecamatan. Potensi ekonomi di Kecamatan Oba Kota Tidore Kepulauan cukup baik untuk menggairahkan sektor agribisnis dalam memasarkan komoditi kopra ketempat tujuan Ternate dan Tidore.

\section{HASIL DAN PEMBAHASAN}

\subsection{Karasteristik Responden}

a. Umur merupakan salah satu faktor yang mempengaruhi para petani dalam mengambil keputusan. Pada penambahan umur juga mempengaruhi kemampuan fisik dalam melakukan aktifitas dan cara berpikir seseorang serta merespon terhadap teknologi baru dan menjamin mutu keterampilan petani dalam mengelola usaha taninya. Pada umumnya petani muda ( 33 - 45 tahun) akan lebih cepat menerima atau merespon hal-hal baru, yang dianjurkan dan lebih berani mengambil resiko kegagalan dalam berusaha dan kurang memiliki pengalaman. Untuk petani yang berusia muda lebih optimis dalam berusaha sehingga lebih cepat pengalaman-pengalaman baru yang bermanfaat bagi perkembangan usaha taninya. Sedangkan petani yang berusia berkisar 46 - 60 tahun atau lebih tua umurnya, lebih matang dalam mngelola usaha dan lebih berhati-hati dalam menentukan suatu pilihan. Dilihat dari 
segi fisik cenderung usia lebih tua petani mulai berkurang dalam melakukan aktifitas yang berhubungan dengan fisik, karena aktifitas yang dilakukan sudah cenderung akan berkurang atau lebih sedikit dibandingkan dengan usia yang masih produktif. Dari hasil penelitian ini data umur yang diperoleh dari petani responden berbeda-beda yaitu umur $33-60$ tahun.

b. Tingkat Pendidikan yaitu merupakan faktor penting dalam mempengaruhi cara berpikir dalam usaha tani. Pendidikan yang diperoleh melalui pendidikan formal disebut dengan sekolah dan pendidikan non formal adalah pendidikan yang diperoleh para petani di luar sekolah. Terkait dengan produksi kopra diperoleh permusim dari tanaman yang dikelola oleh petani. Untuk mengetahui jumlah produksi kopra dapat dilihat pada Tabel. 1

Tabel 1. Jumlah Produksi Kopra di Kecamatan Oba Tidore Kota Tidore Kepulauan, tahun 2009.

\begin{tabular}{|c|c|c|c|}
\hline No & $\begin{array}{l}\text { Produksi } \\
(\mathrm{Kg})\end{array}$ & $\begin{array}{c}\text { Jumlah } \\
\text { (Jiwa) }\end{array}$ & $\begin{array}{c}\text { Prosentase } \\
(\%)\end{array}$ \\
\hline 1 & 300 & 12 & 53.16 \\
\hline 2 & 500 & 7 & 56.84 \\
\hline 3 & 600 & & \\
\hline 4 & 800 & & \\
\hline & Jumlah & 19 & 100 \\
\hline
\end{tabular}

Data hasil penelitian menunjukan, tanaman kelapa yang ada di Kecamatan Oba berproduksi dalam satu tahun sebanyak 2 (dua) kali. Dengan musim panen yang berkesinambungan, dimana panen pertama pada bulan Februari sampai Juli. Dan Panen kedua berkisar pada bulan Agustus sampai Januari. Dari total produksi diperoleh rata-rata pertahun sebesar $1.300 \mathrm{Kg} / \mathrm{Ha}$, dan rata-rata luas lahan yang dimiliki petani responden untuk tanaman kelapa sebesar $1 \mathrm{Ha}$.

Pola Tanam yang dilakukan tanaman kelapa di Kecamatan Oba adalah sistem tanaman tumpang sari yaitu cara menanam dalam satu lahan terdapat beberapa jenis tanaman. Dengan cara ini petani mendapatkan hasil yang berlipat dalam satu lahan tertentu karena selain hasil kopra, juga didapat hasil tanaman lain. Jarak tanam yang dipergunakan oleh petani di lokasi penelitian tergantung dari luas atau sempitnya lahan yang dimiliki yaitu berkisar antara $6 \times 6$ dan $7 \times 7$ M. Hal ini dimaksudkan agar dapat menanam tanaman yang lain.

Tenaga kerja yang dipergunakan dalam usaha tani yaitu tenaga kerja manusia yang berasal dari keluarganya sendiri dan tenaga kerja manusia yang diberi gaji dan ini hanya berlaku pada saat musim panen.

\subsection{Saluran Pemasaran}

Pola pemasaran kopra yang terjadi di Kecamatan Oba sampai saat ini dalam menyalurkan atau menjual hasil kopra dilakukan beberapa cara, diantaranya dari 20 petani responden dalam menyalurkan hasil produksinya berbeda-beda. Dari hasil penelitian ternyata petani yang menjual hasilnya ke pedagang pengumpul desa sebanyak 13 orang atau $68,42 \%$ dan petani yang menjual hasilnya ke pedagang Kecamatan sebanyak 6 orang atau 31,58\%. Hal ini memiliki beberapa alasan, petani yang menjual ke pedagang pengumpul desa karena pertalian kekeluargaan dan cepat memperoleh uang kontan. Sedangkan bagi yang menjual langsung ke pedagang Kecamatan juga memiliki alasan tersendiri yaitu sebagai langganan dan harganya lebih tinggi.

\subsection{Harga Beli dan Harga Jual}

Dari hasil penelitian harga beli dan harga jual kopra pada petani dan harga lembaga pemasaran di Kecamatan Oba tahun 2009.

Dari data penelitian ini dapat dilihat bahwa harga yang terendah terdapat pada pedagang pengumpul Desa dan harga pada pedagang Kecamatan kemudian pada 
pedagang besar dan yang tertinggi pada konsumen.

\subsection{Biaya Pemasaran}

Dalam pemasaran hasil kopra biayabiaya yang dikeluarkan mulai dari petani sampai pada konsumen meliputi biaya pengepakan, retribusi dan pengangkutan. Besar kecilnya biaya-biaya pemasaran untuk suatu komoditi tergantung dari besar kecilnya kegiatan lembaga-lembaga pemasaran dan jumlah fasilitas yang diperlukan untuk proses pergerakanpergerakan barang tersebut mulai dari petani sampai ke tangan konsumen.

\subsection{Keuntungan Pemasaran}

Hasil analisa Keuntungan Pemasaran Kopra maka diperoleh hasil sebagai berikut :

1. Pedagang Pengumpul Desa

$$
\begin{aligned}
& \pi \mathrm{l}=\mathrm{M} \rho \mathrm{r}-\mathrm{B} \rho \mathrm{\imath} \\
& \pi \mathrm{\imath}=2000-40,00 \\
& \pi \mathrm{l}=1960 / \mathrm{Kg}
\end{aligned}
$$

2. Pedagang pengumpul kecamatan

$$
\begin{aligned}
& \pi \mathrm{l}=\mathrm{M} \rho \mathrm{l}-\mathrm{B} \rho \mathrm{l} \\
& \pi_{2}=4000-70 \\
& \pi_{2}=3930 / \mathrm{Kg}
\end{aligned}
$$

Untuk mengetahui beberapa besar keuntungan yang diperoleh setiap lembaga pemasaran di Kecamatan Oba tahun 2009..

\subsection{Margin Pemasaran}

Margin didefinisikan sebagai selisih harga yang diterima olh produsen dengan harga yang dibayarkan konsumen. Analisa margin menyangkut biaya-biaya yang dikeluarkan dan keuntungan yang diperoleh dari kegiatan pemasaran. Hasil analisa Margin Pemasaran kopra maka diperoleh hasil sebagai berikut :

1. Pedagang Pengumpul Desa

$$
\begin{aligned}
& \pi \mathrm{\imath}=\mathrm{M} \rho \mathrm{l}-\mathrm{B} \rho \mathrm{\imath} \\
& \pi_{2}=2000-40,00 \\
& \pi_{2}=1960 / \mathrm{Kg}
\end{aligned}
$$

2. Pedagang pengumpul kecamatan

$\pi \mathrm{r}=\mathrm{M} \rho \mathrm{\imath}-\mathrm{B} \rho \mathrm{\imath}$

$\pi_{2}=4000-70$

$\pi_{2}=3930 / \mathrm{Kg}$

\subsection{Pembahasan}

\subsubsection{Produktifitas}

Berdasarkan hasil penelitian menunjukkan bahwa produksi buah kelapa yang diolah jadi Kopra di Kecamatan Oba sangat tinggi. Hal ini disebabkan luasnya pengetahuan petani menyangkut pemeliharaan tanaman kelapa yang baik.

Menurut Suharjo dan Patong (1984), bahwa usaha tani terwujud ada tiga hal yaitu : (1) Hasil penjualan tanaman, ternak, ikan atau produksi yang dijual, (2). Produk yang dikonsumsi oleh pengusaha atau keluarganya selama dilakukan,

Kenaikan nilai harga investasi.

Terlepas dari sarana produksi sebagai faktor pemeliharaan dalam menunjang pertumbuhan dan perkembangan tanaman, faktor individu petani yang menyangkut umur dan tingkat pendidikan juga sangat penting sebagai penunjang pertumbuhan dan perkembangan tanaman. Tingkat pendidikan petani akan mempengaruhi cara berpikir dalam usaha taninya, misalnya bagaimana cara ia berusaha dalam meningkatkan hasil produksi, tentu ia akan memperhatikan sarana-sarana produksi sebagai salah satu faktor penunjang dalam pemeliharaan dan perkembangan tanamannya.

Dari hasil produksi Kopra di Kecamatan Oba yang tinggi, dan tingginya tingkat pendidikan petani kelapa, dimana petani yang berpendidikan SD menghasilkan $31,54 \%$, petani tingkat pendidikan SLTP 20,78 \% yang berpendidikan SLTA sebesar 34,87 \% dan yang tidak tamat SD menghasilkan 12,81 $\%$ terlihat bahwa petani yang berpendidikan SLTA hasil produksinya lebih tinggi dibandingkan dengan petani yang hanya berpendidikan SD, SLTP dan tidak sekolah, maka dapat disimpulkan bahwa tingkat pendidikan sangat berpengaruh terhadap keberhasilan suatu usaha tani.

Begitu juga halnya umur seperti yang terlihat pada tabel dimana usia 33-45 yang tergolong usia produktif berjumlah 6 
atau 31,58\% dan usia 46 tahun keatas yang tergolong usia tidak produktif berjumlah 13 orang atau $68,42 \%$, hal ini membuktikan bahwa daerah penelitian masih ada kesempatan mengembangkan usaha produksi kopra kearah yang lebih baik untuk tahun-tahun mendatang.

Menurut Soekartawi (1988) bahwa usia muda petani masanya mempunyai semangat untuk tahu apa yang blum mereka ketahui sehingga dengan demikan mereka berusaha untuk dapat melakukan adopsi inovatif walaupun sebenarna mereka belum berpengalaman dalam adopsi tersebut.

\subsubsection{Saluran Pemasaran}

Pemasaran adalah segala kegiatan penyaluran barang-barang dan jasa mulai dari produsen sampai pada konsumen. Dalam rangka memperlancar kegiatan arus barang atau jasa dari produsen ke konsumen, maka salah satu faktor yang tidak boleh diabaikan adalah saluran pemasaran, sebab kesalahan memilih saluran ini dapat memperlambat bahkan memacetkan usaha penyaluran barang atau jasa. Kelemahan dalam bidang pertanian adalah kurangnya perhatian dalam hal pemasaran, hal ini disebabkan karena fungsi tata niaga seperti pembelian, pengangkutan, penyimpanan dan pengolahan tidak berjalan seperti yang diharapkan, sehingga efesiensi menjadi lemah, (Soekartawi 1989).

Saluran dan lembaga pemasaran menurut (Walterts dalam Swastha 1990), Bahwa saluran pemasaran adalah sekelompok pedagang dan agen yang mengkombinasikan antara pemindahan fisik dan nama dari suatu produk untuk menciptakan kegunaan bagi pasar tertentu.

Dalam penyaluran barang-barang dari produsen ke konsumen terlihar satu sampai beberapa golongan pedagang perantara, pedagang perantara ini dikenal dengan saluran tata niaga (Hanafiah dan Saefuddin 1986).

Berdasarkan hasil penelitian, sarana pemasaran kopra yang berlaku di Kecamatan Oba terdiri dari 2 macam yaitu.
1. Saluran pemasaran tidak langsung artinya petani menjual ke Pedagang Pengumpul Desa, Pedagang Pengumpul Desa menjual ke Pedagang Pengumpul Kecamatan, Pedagang Pengumpul Kecamatan menjual ke Pedagang besar/eksportir selanjutnya pedagang besar menjual ke konsumen.

2. Saluran pemasaran langsung artinya petani menjual ke Pedagang Kecamatan, Pedagang Kecamatan menjual ke Pedagang besar/eksportir dan selanjutnya Pedagang Besar menjual ke Konsumen.

\subsubsection{Harga Beli dan Harga Jual}

Secara faktual diketahui bahwa harga merupakan salah satu unsur pemasaran yang sangat penting dan turut mempengaruhi keputusan konsumen untuk membeli. Harga didefinisikan secara sederhana adalah nilai dari suatu barang atau jasa yang diukur dengan uang, dimana berdasarkan nilai tersebut seorang atau produsen bersedia melepaskan barang atau jasa yang dimiliki kepada pihak lain.

Segala kegiatan dan usaha yang berhubungan dengan pemindahan hak milik dan fisik dari barang-barang hasil pertanian dan barang-barang kebutuhan dan usaha pertanian dari tangan yang satu ke pihak lain atau dari produsen ke konsumen.

Dari hasil penelitian menunjukan bahwa harga jual petani yang terendah terdapat pada pedagang pengumpul desa sebesar Rp 32.000 /Kg, Kemudian yang tertinggi adalah pedagang kecamatan $\mathrm{Rp}$ $34.000 / \mathrm{Kg}$ dan apabila petani menjual langsung ke pedagang besar dan konsumen tidak dilaksanakan karena modal untuk memasarkan produksi sangat terbatas.

\subsubsection{Biaya Pemasaran}

Biaya pemasaran adalah biaya-biaya yang dikeluarkan dalam proses pergerakan barang dari tangan produsen ke tangan konsumen. Besar kecilnya biaya pemasaran untuk hasil pertanian tergantung dari besar kecilnya kegiatan lembaga-lembaga pemasaran dan jumlah fasilitas yang 
diperlukan dalam proses pergerakan barang tersebut.

Menurut Soekartawi (1995), Mengemukakan bahwa biaya adalah keseluruhan masukan yang mempengaruhi produksi dan digunakan dalam proses produksi yang dibagi dalam dua bagian yaitu : Biaya tetap (Fixed cost) adalah jenis biaya yang besar kecilnya tidak tergantung pada besarnya produksi, seperti : Biaya peralatan produksi, penyusutan dan peralatan mesin, sedangkan biaya tidak tetap adalah jenis biaya yang besar kecilnya produksi yang meliputi biaya pembelian bahan baku atau upah tenaga kerja dan biaya pemasaran.

Berdasarkan hasil analisa biaya pemasaran kopra di Kecamatan Oba, biaya pemasaran yang cukup besar ditanggung oleh pedagang pengumpul kecamatan $34.000 \mathrm{Kg}$, kemudian pada pedagang pengumpul desa sebesar $32.000 / \mathrm{Kg}$.

\subsubsection{Keuntungan Pemasaran}

Untuk mengetahui tingkat keuntungan yang diperoleh dari setiap satuan biaya yang dikeluarkan dapat diketahui dengan membandingkan total penerimaan dengan total biaya yang dikeluarkan.

Data yang diperoleh ditabulasi dan dianalisa berdasarkan distribusi dan ratarata dan dihitung, untuk mengetahui analisa penyebaran harga dari produsen ke konsumen dengan menggunakan rumus dari Soekartawi (1989).

Hasil analisa keuntungan pemasaran kopra diperoleh hasil sebagai berikut :

1. Pedagang pengumpul desa $\pi_{2}=3.000 / \mathrm{Kg}$

2. Pedagang pengumpul kecamatan $\pi_{2}=34.000 / \mathrm{Kg}$

Dari kedua lembaga pemasaran yang ada ternyata pedagang pengumpul kecamatan yang mendapatkan keuntungan lebih besar dibandingkan dengan pedagang pengumpul desa yang memperoleh keuntungan paling rendah. Keuntungan yang diterima oleh pedagang pengumpul kecamatan merupakan hal yang wajar karena begitu banyak kegiatan pemasaran, fasilitas, jasa, serta biaya yang dikeluarkan, sehingga pedagang pengumpul kecamatan menjual kopra relatif tinggi.

\subsubsection{Margin Pemasaran}

Dari hasil analisa margin pemasaran diperoleh hasil sebagai berikut :

1. Pedagang pengumpul desa $\mathrm{M} \rho \mathrm{r}=52.000 / \mathrm{Kg}$

2. Pedagang pengumpul kecamatan $\mathrm{M} \rho \mathrm{\imath}=54.000 / \mathrm{Kg}$

Margin pemasaran adalah selisih antara harga yang diterima produsen dengan yang dikerjakan oleh konsumen. Analisa margin pemasaran menyangkut biaya-biaya yang dikeluarkan oleh lembaga yang terlibat dalam sistim pemasaran kopra dalam proses penyampaian dari produsen ke konsumen dan keuntungan yang diperoleh dari kegiatan pemasaran tersebut. Dalam sistim pemasaran kopra diketahui bahwa terdapat 2 lembaga pemasaran yang terlibat dalam menyalurkan kopra sejak petani produsen sampai ke konsumen akhir. Dari kedua lembaga tersebut pedagang pengumpul kecamatan memiliki margin pemasaran yang lebih besar dibandingkan dengan margin pemasaran pada pedagang pengumpul desa. Hal ini disebabkan karena pedagang besar melakukan fungsi pemasaran atau kgiatan yang lebih banyak yang mana kegiatan ini akan meningkatkan biaya pemasaran yang akhirnya memperbesar margin pemasaran.

\section{KESIMPULAN DAN SARAN}

\subsection{Kesimpulan}

Berdasarkan hasil penelitian dapat disimpulkan sebagai berikut :

a. Sistim rantai pemasaran yang terdapat di Kecamatan Oba yaitu sistim pemasaran tidak langsung yaitu petani menjual ke Pedagang Pengumpul Desa, Pedagang Pengumpul Desa menjual ke Pedagang Pengumpul Kecamatan, Pedagang Pengumpul Kecamatan menjual ke Pedagang besar selanjutnya pedagang besar menjual ke Konsumen. 
b. Saluran pemasaran langsung yaitu Petani menjual ke Pedagang Kecamatan, Pedagang Kecamatan menjual ke Pedagang besar selanjutnya Pedagang Besar menjual ke Konsumen. Hasil perhitungan margin pemasaran untuk tiap lembaga pemasaran berbeda satu dengan yang lainnya. Margin yang diperoleh pedagang pengumpul desa adalah dengan biaya Rp. 52.000,- serta keuntungan yang diperoleh. Margin yang diperoleh pedagang kecamatan adalah dengan biaya Rp. 54.000,- serta keuntungan yang diperoleh.

\subsection{Saran}

1. Untuk petani produsen jika ingin mendapatkan keuntungan yang lebih besar dari hasil penjualan kopra maka sebaiknya dijual langsung ke pedagang pengumpul kecamatan atau eksportir.

2. Untuk mengubah pola pemasaran yang ada di Kecamatan Oba perlu juga diadakan penelitian lanjutan.

\section{DAFTAR PUSTAKA}

Haian dan Schewe, C,D 1994. Pemerasan, Bina Putera Aksara, Jakarta.

Hanaflah dan Saefuddin, A.M. 1986. Tata Niaga Hasil Pertanian.

Keegan, WJ.1996. Manajemen Pemasaran Global, Terjemahan Sindro Prenhallindo, Jakarta.

Kotler, P. 1997. Manajemen Pemasaran, Edisi Bahasa Indonesia. Terjemahan Hendra Dkk.

Mubyarto, 1995. Pengantar Ekonomi Pertanian, LP3ES., Jakarta.

Mulyadi, 1991, Akuntasi Biaya, Edisi 5, Bagian Penerbitan STIE YKPN, Yogyakarta.

Soekartawi. 1993. Prinsip Dasar Manajemen Pemasaran Hasil-Hasil Pertanian (Teoridan Aplikasi). Rajawali Press, Jakarta .,1995. Pengantar Menejemen Agribisnis, Rajawali Press, Jakarta

Suhardiman. P. 1994, Bertanam Kelapa Hibrida. Penebar Swadaya Jakarta.

Suhardiyono, L. 1993. Saluran Pemasaran, Konsep \& Strategi Analisa Kuantitatif, BPFEUGM, Yogyakarta.

Swastha, Menejemen dan Biaya Pemasaran Komoditi Pertanian, Bina Putera Aksara. Jakarta.

Walters dan Swastha, 1989, Pemasaran Komoditi Pertanian, Bina Putera Aksara, Jakarta. 